\title{
Adopting Passing off Concept of Unfair Competition Into Indonesia's Trademark Law
}

\author{
Ali Oksy Murbiantoro, Rachmad Safa'at, Yuliati \& Sukarmi \\ Brawijaya University, Faculty of Law, Malang, INDONESIA
}

Received: 19 June 2020 - Accepted: 30 September $2020 \cdot$ Published Online: 8 November 2020

\begin{abstract}
The application of the concepts of unfair competition in Indonesia's Trademark Law is one of the reasons as a proper solution in providing justification and argumentation basis, in terms of to answer the issue of impersonation of trademarks on different kinds goods, particularly for impersonation of domestic well known mark obtains sufficient legal basis due to the existence of protection and legal certainty for the trademark owner which is impersonated thereof. The current Indonesia trademark law basically only provide trademark lawsuit in terms of cancellation for registered mark; legal damages claim. Both lawsuits related to using unauthorized registered mark based on overall or basic similarities in the same kind of goods, although unauthorized use in different kind of good is possible to be sued but it is restricted for international well-known mark only. In addition there is such trademark lawsuit in connection with deletion registered mark means this proceeding enforce when the registered mark does not use for three years as of the mark registered. Considering that actually the concept of unfair competition basically reflect to the understanding of unlawful act (tort) which stating in the article 1365 Indonesia's Civil Code. However, this understanding is not covered in Indonesia's Trademark law instead of it is enforced in Indonesia's civil law and civil procedure. Hence, if there is a trademark impersonation dispute in the different kinds of goods, the resolution of the dispute will refer to unlawful act and that lawsuit will be trialed by regular district court, even though based on trademark law for trademark lawsuit should be trialed by commercial court. Therefore, it is lead to uncertainty in terms of the authorize court which is examined and handled the said case. To include the concept of unfair competition as a part of trademark violation into Indonesia's trademark law hopefully enable to anticipate in reducing any kind of types trademark violation occurred including in the form of violation such impersonation of domestic well-known mark in different kind of goods. This research is normative legal research with a legislation, concept, and comparative approach. The legal material with technical analysis is done by the method of interpretation. Comparing to the concept of unfair competition, passing off within Indonesia's trademark law; International Trademark Convention will answers whether the understanding of unfair competition applied in the trademark violation in Indonesia particularly in connection with the issues of impersonation towards registered of well-known mark domestically is already proper either for domestic or worldwide perspective.
\end{abstract}

Keywords: impersonation, different kinds of goods, unfair competition, well-known mark, domestically well-known mark, Article 21 Paragraph 3 of Indonesia's Trademark Law, Article 16 Paragraph 3 of TRIPs, Article 6 of the Paris Convention.

(C) Authors. Terms and conditions of Creative Commons Attribution 4.0 International (CC BY 4.0) apply. Correspondence: Ali Oksy Murbiantoro (Student at Faculty of Law), Brawijaya University, Malang, East Java, INDONESIA. E-mail: murbiantoro.fhub@gmail.com. 


\section{Introduction}

The issue of impersonation of trademarks on different kinds goods, particularly for impersonation of domestic well-known mark no sufficient legal basis for the trademark owner which is impersonated to sue and to obtain remedy from the infringer considering that there is unclear provision stating in the trademark law. In practice, alternatively this case is proceeded refer to unlawful act (tort) as civil lawsuit, meanwhile in fact the case can be classified as trademark matters. Based on Indonesia's trademark law for trademark infringement becomes commercial court authority to examine and to trial the case. Hence, it leads to confuse which courts that having authorization in properly. This situation will impact to trademark owner in obtaining their legal protection.

According to Paris Convention (1967), which the convention deals with trademark subject matters, and Indonesia as one of member of the convention in article 10 basically govern that:

(a) Countries of the Union are bound to assure to nationals of such countries effective protection against unfair competition.

(b) Any act of competition contrary to honest practices in industrial or commercial matters constitutes an act of unfair competition.

(c) The following in particular shall be prohibited:

(1) All acts of such a nature as to create confusion by any means whatever with the establishment, the goods, or the industrial or commercial activities, of a competitor; (2) False allegations in the course of the trade of such a nature as to discredit the establishment, the goods, or the industrial or commercial activities, of a competitor; (3) Indications or allegations the use of which in the course of trade is liable to mislead the public as to the nature, the manufacturing procces, the characteristics, the suitability for their purpose, or quantity, of the goods.

Then, Article 1 (iii) of WIPO define unfair competition s as follows:

"Act of unfair competition means any act of competition contrary to honest business practices in industrial or commercial matters as defined in Article 10 of the Paris Convention for the protection of industrial property, signed in Paris on 20 March 1883, as revised and amended" (Charles, 2014: 6), mentioning that "unfair competition", but in a number of early cases involving attempts by one merchant to palm off inferior goods as those of another more reputable merchant by making deceptive use of the other merchant's trademark.

The issue of unfair competition as above mentioned different from countries (United States, Singapore, United Kingdom) which recognize unfair competition as passing off which is included in the part of trademark law. Basically by including this concept as a part of the trademark law which regulates with legal certainty in terms of providing legal basis for trademark violation that is not restricted directly to connect a common issue of overall and/or basic similarities in similar goods either for the proceeding of cancellation or legal damages (compensation). However, under passing off is also cover a trademark violation deals with impersonation of mark in the different kinds of goods.

Mary La France (La France, 2012) said that in the United States the meaning of unfair competition is identical or as a synonym for "passing off" (in the United States, however, "unfair competition" is tipically used as a synonym for "passing off").

The concept of passing off from a philosophical point of view is the rules of trademark law which grow from the values of recognition and respect for identity rights which are then crystallized into norms of protection. At this point, written law is not yet intensively developed, and in line with common law culture, legal norms are formed from a series of judges' decisions on relevant cases that have been decided by the court. It must be recognized that the concept of 
passing off action also underlies and becomes the pillars of trademark law. This conception establishes norms that separate right or wrong behavior in the eyes of justice and legal rationality. Any behavior that is misleading to the public and is incorrectly categorized, is clarified as an act of passing off. Margreth Barrett gives the meaning of passing off namely: "Passing off accurs when the defendant makes one form the false representation that tends to cause consumers to believe that the defendant's goods or services come from the plaintiff."

Hillary E. Pearson and Clifford G. Miller provide the following understanding of passing off: "Passing off occurs where a trader confuses or deceives the public about the identity of his or her business, products or services. Where the public is led to believe that the business, products or services are those of another trader or are connected with another trader, and that other trader's business or trading goodwill is likely to be damaged". Copinger, as quoted by Muhammad Djumhana and R. Djubaedillah, gives the meaning of passing off as follows: "The action for passing off lies where the defendant has represented to the public that his goods or business are the goods or business of the plaintiff. A defendant may make himself liable to this action by publishing a work under the same title as the plaintiff's or by publishing a work where 'get-up' so resemble that of the plaintiff's work as to deceive the public into the belief that it is the plaintiff's work, or is associated or connected with the plaintiff." The three basic elements of passsing off commonly called classic trinity are: (1) Goodwill / reputation related to the consumer's desire to buy goods that are related or part (related) to a particular brand; (2) wrong in assuming the origin of the goods; and (3) allows for goodwill to arise.

The case of passing off for instance related to a producer/ a maker of vodka in bringing such a claim against the manufacturer of Vodkat, an alcoholic beverage that did not meet the legal requirements to be marketed as Vodka under European law. The term Vodkat did not resemble the trademark used on any particular brand of vodka and thus could not be challenged under a traditional passing off theory. Nonetheless, it was actionable under the broader theory because it implicitly misrepresented the nature of product. The Vodkat case is particularly notable because it was the first to hold that extended from passing off is not limited to prestige or luxury product. Even a generic term such vodka, in the court's view, has a reputation sufficient to give rise to goodwill.

In civil law countries passing off is defined as unfair competition such as unfair competition remedies for unauthorized merchandising have been especially strong in Austria. When emblem of an English football club was used on merchandise without the club's consent, the Austrian Supreme Court held the defendant liable for parasitic exploitation of the emblem was attractive to consumers was because it signified the club's achievements, which were the result of the club's efforts and effort/expense/achievement rationale in later cases involving noncompeting goods and services. Even though there is exception even in the civil law country for instance in the case the mark of Opel. In 2011 Germany's highest court refused to find either a likelihood or the taking of unfair advantage where Defendant sold remote controlled scale model replicas of the Astra that featured the Opel logo (a registered trademark) affixed to the grille. Even though Opel had registered this mark both for motor vehicles and toys the Bundesgerichtshoh (BGH, Federal Court of Justice) considered the fact that the replica car market in Germany had existed since the late nineteenth century, presence of the mark simply as one of the details necessary to making an accurate replica of the Opel Astra. A European commentator notes, however, that in other civil law jurisdictions the same fact might lead to different conclusion, taking into account local customs and views relating to (toy) cars (La France, 2012: 1112-1113).

The concept of unfair competition and passing off in Indonesia similar with unlawful act (tort) as stating in the Article 1365 of Indonesia's Civil Code. Unfortunately, the provision of the Article 1365 of the Civil Code is not as part of Indonesia's Trademark Law. Based on this article Prof. Mariam Darus stating that unlawful act including the criteria namely: 
(1) Occurs both positively and negatively;

(2)Actions must be against the law;

(3)There are losses;

(4)There is a causal relationship between breaking the law and loss;

(5) There is an error.

Rachmat Setiawan in terms of unlawful act stating that who opposed the law consisting of 4 petitions namely:

(1) Violate the rights of others;

(2)Contrary to the challenges of lawmakers;

(3) Contrary to good morality; or

(4) Contradicts the propriety in society of oneself or other people's property.

Unlawful act has been interpreted more broadly in the Netherlands since 1919, which is to choose one of the following actions:

(1) Acts that is contrary to the rights of others;

(2)Acts that is contrary to their own legal requirements;

(3)Acts that oppose morality; and

(4)Actions that is contrary to prudence or conflict in good community relations.

Some decisions that can be submitted because of actions against the law are:

(1) Compensation for damages in the form of money for losses incurred;

(2)Compensation for damages in kind or returned in original condition;

(3) Statements, actions taken against the law; and

(4) Prohibit certain actions.

\section{Research methods}

In connection with this, in this study using normative legal research methods, namely legal research conducted by examining materials derived from various laws and regulations, namely TRIPs, Paris Convention, WIPO Rules, Indonesia's Trademark Law, Law No. 20 of 2016 concerning marks and geographical indication and other materials from various literatures. In other words, this research examines literature or secondary data. The study of legal normative here is due to the ambiguity of norms, namely that there is a lack of clarity about the norms in determining the terms and criteria for well-known brands contained in the Indonesia's Trademark Law related to the provisions of the international convention of TRIPs, Paris Convention. Besides that, it is also related to the possibility of legal protection for registered brands if there is imitation of non-similar goods.

3. Result and discussion

3.1 Need a redefinition of trade mark violation in the trademark law

The legal basis for trademark violation under Indonesia's Trademark Law is governed and refers to Article 21 Paragraph $1 b$, c, Article 76 (cancelation lawsuit), Article 83 (legal 
damages/compensation lawsuit), Article 100 (criminal sanctions) based on Article 21 Paragraph (1) Subparagraph $b$ and Subparagraph $c$ of the 2016 of Indonesia's Trademark Law has stipulates that an application of mark is rejected if the mark has basic similarities or in entirety with:

(a) The registered mark belongs to another party or has been applied in advance by another party for similar goods and/or services;

(b) Well known mark belongs to other parties for similar goods and/or services;

(c) Well known mark belongs to other parties for different kind of goods and/or services which meet with the specific requirements (will be further regulated).

Referring to provision (Point $c$ ) based on Supreme Court's circular letter 2012 stating that considering up until now such a regulation concerning in determining of trademark violation in terms of impersonation of the mark, including a well-known mark in different kind of goods has not been enacted therefore the legitimate owner of mark in case of well-known mark is not entitle to object or to take legal action against third parties who conduct to imitating of their mark in different kind of goods. Under Indonesia's Trademark Law the requirement of well-known mark must be the mark which is the product commercialized as well as registered internationally. Therefore, the registered mark with the products or services which is recognized and well known within Indonesian territory no opportunity to obtain status as a well-known mark, consequently for local registered well known mark's level impossible in obtaining protection such as to take objection and/or to bring a lawsuit against third parties who imitating their registered mark in different kind of goods. In other words based on Indonesia's Trademark Law the criteria of a wellknown mark restricted to international mark only which is well-known globally. Therefore, the issue of a legal protection of registered mark against impersonation for different kinds of goods and a criteria or requirement of well-known mark is inherently or dependence between each other. Actually, this rule is not appropriate with the provisions of TRIPs and Paris Convention. Article 16 Paragraph 3 and Paris Convention do not regulate such requirements for well-known mark must be commercialized and registered internationally Article 16 Paragraph (3) of TRIPs:

Article 6 of the Paris Convention (1967) shall apply, mutatis mutandis, to goods services which are not similar to those in respect of which trademarks registered, provided that use that trademarks in relation to those goods or services would indicate a connection between those goods or services and the owner of the registered trademarks and provided that the interest of the owner of the registered tardemarks are likely to be damaged by such use.

Article 6 of the Paris Convention:

Article 6 [Marks: Well-Known Marks] (1) of the Paris Convention: the countries of the Union undertake, ex officio if their legislation so permits, or at the request of an interested party, to refuse or to cancel the registration, and to prohibit the use, of a trademark which constitutes a reproduction, an imitation, or a translation, liable to create confusion, of a mark considered by the competent authority of the country of registration or use to be well known in that country as being already the mark of a person entitled to the benefits of this Convention and used for identical tor similargoods. These provisions shall also apply when the essential part of the mark constitutes a reproduction of any such well-known mark or an imitation liable to create confusion therewith.

On the basis of those provisions showing that there is no requirement to be a wellknown mark must be commercialized and registered internationally instead of under joint recommendation of WIPO basically rules that a protection of well-known mark that means, member of country no need to protect an internationally known mark if that mark is not well known domestically. Also, the protection to be given to well- known mark at least with effect from the time when the mark has become well-known in the Member State, WIPO Joint Recommendation in September 1999 (Ong, 2005: 95, 126). 
Further, the urgency to find out justification for impersonation offenses of trademark in different kind of goods as legal basis is with inserting the concept of unfair competition or passing off into Indonesia's trademark law. It is appropriate with the theory of law and economics, whereas in determining trade name by producer (manufacturer) is not a simple way, considering that it is as a part of strategic concept of marketing and selling. Actually, the product can be quickly recognized by the public of consumers as new producers (manufacturer) using the same name of product or having similarities with name of products which have already been known in the market previously. However, if this is done by the new producer referred to goods similar to their product, consequently will violate Article 21 Paragraph (1) $a$ of Indonesia's Trademark Law of 2016. Otherwise If the product to be marketed uses a mark/brand which has similarities with the goods in different kinds of goods (not in the same type) that means contrary to Article 21 Paragraph (1) $c$ of the 2016 Trademark Law that is related to a well-known mark with criteria the mark must be registered and commercialized overseas. Therefore, a registered mark that is not included into the said criteria of a well-known mark does not obtain legal protection when the mark is imitated by another producer (manufacturer). Based on perspective of Law and Economics theory stating that rationally economic actors will always effort to achieve and maximize the level of economic satisfaction even though this is related to unlawful acts, as long as the costs incurred for the settlement, it is necessary to have an economic target to be achieved. Therefore, the condition of the absence of rules/legal protection against trademark impersonation in different kinds of goods giving huge opportunity for business actors who in bad faith to shorten profits by violating the rights of registered trademark. Then, another perspective of law and economic theories relates to applying the concept of the legal rule as a Consideration (Price). In the economy the level of illegal actions can be reduced by increasing the value of fines for the violator. If to analogize for the imitation of the mark/brand in different kinds of goods considering that there is no clear regulation imposing to violators therefore in this regards needs to be governed (Mercuro \& Medema, 1996: 51).

We believe that based on above illustration indicates that the issue of impersonation of trademark in different kind of goods in Indonesia is considered and inherently as unfair competition and passing off concept. This can be found in the trial of Commercial Court at the Central Jakarta District Court No. 39 / Brand / 2011 / PN. Commerce Jkt. Pst. in case of a trademark between IKEA (Inter IKEA Systems B. V.) originating from Sweden and the product of its goods registered as a mark in Indonesia in several classes with the Registration Number: IDMo00092006 (class 21); IDM000092007 (class 24); IDMooo092008 (class 11); IDMooo092009 (class 35) and IDMooo092010 (class 42) against IKEMA (PT. Angsa Daya) an Indonesian legal entity registered as a trademark with registration No. IDM 000247161 for class of goods 19. The IKEA brand, besides being registered in Indonesia, is also registered in 75 countries. As for the case, the court ruled in principle that: granting the lawsuit filed by IKEA, stated the registration of the IKEMA mark was carried out in bad faith, declaring IKEA to be a well-known mark and the registration of the IKEMA mark must be canceled. In the IKEA vs. IKEMA Trademark Case, whose case is registered under Number: 39 / Trademark / 2011 / PN. Commerce Jkt. Pst. In this case the object of the lawsuit is regarding brands with different classes of goods (types of goods). Then the commercial court's decision was corroborated by MA-RI's decision No. 697 K / Pdt.Sus / 2011. However, the cassation decision was canceled with Judicial Decision No. 165 PK / Pdt Sus / 2012 which basically states granting the Petitioner / Defendant I Review Appeal cancels the cassation decision with the consideration that the IKEMA trademark is in class 19 which is different from the IKEA brand and the provisions of Article 6 Paragraph (2) of the 2001 Trademark Law are not can be applied in a quo case because Government Regulations governing certain conditions have not yet been regulated, namely to apply equality in principle to goods of different classes so that the provisions of the convention cannot be implemented. Based on the supreme court decision indicated that Indonesia's trademark law had not recognized yet 
legal protection for real trademark owner who their mark is impersonated by third party in different kind of goods.

In another case the court in render consideration of decision is more appropriate with the international convention (Article 16 Par. 3 of TRIPs and Article 6 of the Paris Convention) and giving protection to the trademark owner, although the point of consideration was not regulated and stated in Indonesia's trademark law. In can be found in the trademark case of BARBIE with the parties: plaintiff is MATTEL INC, United States, against Hendri Subun Kangdani, Jakarta, as defendant. In such case the plaintiff as the owner of the BARBIE trademark to protect the goods: fashion dolls (BARBIE dolls and their equipment and related products). In that case, the plaintiff objected to the registration of the BARBIE trademark conducted by the defendant to protect the kinds/types of goods: office equipment and school equipment, including bookbinding equipment, stationery, adhesive materials (for writing), educational and teaching tools except the tools, playing cards, printed letters, cliches, eraser liquid, writing eraser paper, book and paperclip tool, dapper (stepler), scratching devices, tools paper holes, pencil scrap, term, typewriter, tacks, eraser, stamp, pencil box, imitation leather and leather, fine skins, suitcases, and bags, purses, umbrellas - rain umbrellas and sun umbrellas, sticks, whips, horse clothes, and saddles, beaty cases made of leather, etc. Regarding the registration of the mark, the plaintiff has filed a cancellation claim at the Central Jakarta District Court. The legal considerations of judges in the Central Jakarta District Court include:

(1) Based on the evidence the plaintiff's brand has long penetrated national and regional boundaries, so the plaintiff's trademark has been globalized and can be referred to as a brand that knows no world boundaries. The plaintiff's brand has entered Indonesian territory as a product of dolls with the brand BARBIE and has been widely circulated and everyone who uses the brand has its own taste compared to other brands;

(2) Although the results of the plaintiff and defendant's products are not classified as one type, it is not a problem because based on the permanent jurisprudence of the Supreme Court it is not important whether or not the product/service is similar, because the mark is to provide identification about the origin of the item not the type of goods;

(3) Grant the plaintiff's claim, declaring the defendant's mark to be null and void.

\subsection{US rule of passing off}

Unfair competition in the US is recognized with passing off or trademark unfair competition: "passing off" outside the trademark arena, the idea of unfair competition exists in common law and statutes to composite business that have suffered an injury party can bring an unfair competition claim in the Lanham Act. This act containing of trademark provisions. In terms of trademark unfair competition is governed under Section $43(a)$ of the said act which states that:

- Any person who, on or in connection with any goods or services, uses in commerce any word, term, name, symbol or device or any false or misleading representation of fact which, is likely to cause confusion, or to cause mistake, or to deceive as to the affiliation, connection, or association of such person with another person or origin;

- In commercial advertising or promotion, misrepresents the nature of his or her or another person's goods services or commercial activities, shall be liable in any civil action.

Passing off encompasses a lot of activity and is the oldest theory of unfair competition. Passing off happens when the defendant makes statement or representation that goods or services 
are affiliated or come from the plaintiff. There can be direct or indirect false representation in this regards. An example of direct representation is when the seller/defendant claims the products are actually from plaintiff. It can happen indirectly when a customer places an order for plaintiff's product, but the order is actually filed with defendant's product. To be liable for passing off a defendant must simulate the plaintiff's mark, trade dress or trade name and plaintiff's product, but the order is actually filed with deffendant's product.

Based on the Lanham Act shows that understanding of trademark violation is broader than what Indonesia's trademark law governed that means in Lanham act trademark violation deals included with unlawful act/tort action that is related to trademark issues happened, meanwhile, under Indonesia's trademark law the its scope is not restricted directly to connect a common issue of overall and/or basic similarities in similar goods either for the proceeding of cancellation or legal damages (compensation). In commercial advertising or promotion, misrepresents the nature of his or her or another person's goods services or commercial activities, shall be liable in any civil action.

\subsection{EU unfair competition}

Most civil law jurisdiction interpret unfair competition to include many practices that do not involve deception. According to the CJEU (Court of Justice of European Union), the requirement of honest practices in industrial or commercial matters, as reproduced in Article 6 (1) of the EC Trade Mark Directive, implies a duty to act fairly in relation to the legitimate interest of the trademark owner, language that leaves much room for interpretation, and that has been criticized as circular. The CJEU has identified as unfair not only those uses that misleadingly suggest a commercial connection between two parties, but also those that take unfair advantage the distinctive character or repute of a mark, those that discredit or denigrate a mark, and those that present a product as an imitation or replica of the trademark owner's product.

The term "free riding" has been used to describe the kinds of non-deceptive activities that may constitute unfair competition. The World Intellectual Property Organization (WIPO) has defined free riding as any act that ac competitor or another market participant undertakes with intention of directly exploiting another person's industrial or commercial achievement for his own business purposes without substantially departing from the original achievement.

Therefore, here we believe that free riding can be analogized as unlawful act or tort action which basically containing bad faith intention from the actor/defendant as well as is occurred in the passing off action. Hence, either unfair competition or passing of the purpose is to provide a legal basis for trademark owner to obtain remedy in terms of unauthorized party using their mark (La France, Op. Cit.: 1098).

\section{Conclusion}

The concepts of unfair competition and passing off basically reflect to the understanding of unlawful act (tort) which stating in the Article 1365 of the Indonesia's Civil Code. However, this understanding is not included in Indonesia's Trademark Law instead of it is regulated in Indonesia's civil law and civil procedure. Should there is a trademark impersonation dispute in the different kinds of goods, the resolution of the dispute will refer to unlawful act and that lawsuit will be trialed by district court. To include the concept of unfair competition/passing off as a part of trademark violation into Indonesia's Trademark Law enable to answer in reducing any kind of types trademark violation occurred including in the form of violation such impersonation of domestic well-known mark also providing a provision which becomes legal basis to examines trademark dispute excluded for regular trademark lawsuit namely cancelation and 
legal damages lawsuit which refer to overall and/or basic similarity in the same kinds of goods. Hence, trademark law possible deals to related to trademark violation such as commercial advertising or promotion, trade dress, misrepresents the nature of his or her or another person's goods services or commercial activities.

\section{Acknowledgements}

This research did not receive any specific grant from funding agencies in the public commercial, or not-for-profit sectors.

The authors declare no competing interests.

\section{References}

Ball, E. (2016). Trademark owners may find dilution claims out of reach. Fenwick \& Wess LLP. Available at https://www.fenwick.com/insights/publications/almost-famous-trademark-owners-mayfind-dilution-claims-out-of-reach.

Cornell Law School (2019). Trademark infringement. Available at https://www.law.cornell.edu/wex/trademark infringement. Accessed on January 2019.

Gunawati, A. (2015). Perlindungan merek terkenal barang dan jasa tidak sejenis terhadap persaingan usaha tidak sehat [Protection of famous brands of different goods and services against unfair business competition]. Malang: Briwijaya University.

International Trademark Association (2017). Trademark dilution (Intended for a non-legal audience). Available at https://www.inta.org/TrademarkBasics/FactSheets/Pages/Trademark-Dilution(Intended-for-a-non-legal-audience).aspx. Accessed on January 2019.

International (Nice) Classification of Goods and Services (2020). Wikipedia, the free encyclopedia, Available at https://en.wikipedia.org/wiki/International_(Nice)_Classification_of_Goods_and_Services. Accessed on February 2020.

Janed, R. (2006). Penyalahgunaan hak eksklusif hak kekayaan intelektual [Abuse of exclusive rights of intellectual property rights]. Surabaya: Airlangga University.

LaFrance, M. (2012). Passing off and unfair competition conflict and convergence competition law. The Law Journal of the International Trademark Association, 102(5).

Manis, C. R. M. C. (2014). Intellectual property and unfair competition. Nutshell: West Publishing Co.

Mark, D. R. (2004). Actual confusion in trademark infringement litigation: Restraining subjectivity through a factor-based approach to valuing evidence. Journal of Technology and Intellectual Property, 2.

Mercuro, N., \& Medema, S. G. (1996). Economics and the law from posner to post-modernism. Princeton University Press, New Jersey.

Narthy, J., \& Thomas, Mc. (1995). Intellectual Property. In Mc Narthy on trademarks and unfair competition. USA: Thomson Legal Publishing, Third Edition.

Ong, B. (2005). Protecting well-known trade marks: Perspsective from Singapore. The Law Journal of the International Trademark Association, 95(6).

Sommers, M. (1999). Taking an aggressive stance against counterfeiters: An overview of trademark counterfeiting litigation under the Lanham Act, September/October. 
A. O. Murbiantoro et al. - Adopting Passing off Concept of Unfair Competition Into...

United States Paten and Trademark office (USPTO) (2019). Well-known marks. Available at https://www.uspto.gov/ip-policy/trademark-policy/well-known-marks. Accessed on November 2019.

Walker, J. T. (2017). Beware of facilitating counterfeiting and trademark infringement. Published in NH Bar News.

Well-known trademark criteria in Malaysia and Japan (2019). Available at https://open.mitchellhamline.edu/cgi/viewcontent.cgi?article=1142\&context=fach. Accessed on January 2019.

Word Intellectual Property Organization (WIPO) (2020). Available at www.wipo.int. Accessed on February 2020. 